\title{
Preliminary Characterization of an Antibiotic Produced by Xanthomonas albilineans Which Inhibits DNA Synthesis in Escherichia coli
}

\author{
By ROBERT G. BIRCH† AND SURESH S. PATIL* \\ Department of Plant Pathology, University of Hawaii, Honolulu, HI 96822, USA
}

(Received 18 July 1984; revised 14 October 1984)

\begin{abstract}
Chlorosis-inducing isolates of Xanthomonas albilineans, the sugarcane leaf scald pathogen, produced a mixture of antibacterial compounds in culture. The antibiotic mixture, which eluted as a single strongly retarded peak from Sephadex LH-20 in methanol, was bactericidal to Escherichia coli. Inhibition of $E$. coli was not reversed by added nutrients, and affected cells were not lysed but many accumulated polyphosphate granules. The major antibacterial component, isolated in crystalline form after HPLC, is given the trivial name albicidin. Near the minimum inhibitory concentration, albicidin caused a complete block to DNA synthesis, followed by partial inhibition of RNA and protein synthesis, as assessed by incorporation of radioactive precursors. Spontaneous antibiotic-resistant mutants of $E$. coli showed no cross-resistance between albicidin and inhibitors of either subunit of DNA gyrase. Mixing albicidin with purified DNA from E. coli did not alter the thermal denaturation behaviour of the DNA, or the absorption spectrum of the antibiotic. PolA ${ }^{+}$and PolA- strains of E. coli were equally sensitive to albicidin, indicating that the antibiotic does not bind to or modify DNA. Selective inhibition of DNA synthesis without evidence of DNA binding suggests a specific interaction of albicidin with an essential replication protein.
\end{abstract}

\section{INTRODUCTION}

Xanthomonas albilineans is a xylem-invading bacterium causing leaf scald disease of sugarcane. Chlorosis of emerging leaves is a characteristic symptom of the disease. A recent ultrastructural study demonstrated that chlorosis results from blocked chloroplast differentiation in parenchyma surrounding invaded xylem vessels, and in uninvaded white leaves emerging after invasion of sugarcane stalks by the pathogen, suggesting involvement of a diffusible phytotoxin (Birch \& Patil, 1983). Attempts to induce chlorosis in sugarcane with fractions from $X$. albilineans cultures have not been successful, and further investigation of the phytotoxin would normally be difficult without such a bioassay. However, we observed that five tested chlorosis-inducing isolates of $X$. albilineans produced a microbial inhibitor in culture, whereas an exceptional non-chlorosis-inducing isolate failed to produce the microbial inhibitor (R. G. Birch, unpublished observations). Toxins of several phytopathogenic pseudomonads possess antimicrobial activity (Gasson, 1980; Staskawicz \& Panopoulos, 1979). The chemical nature and mode of action of the antibiotic from $X$. albilineans was investigated to help clarify its relationship to the putative chlorosis-inducing phytotoxin.

This report describes conditions for production and purification of the antibiotic, chemical characteristics of the isolated major bactericidal component (which we have named albicidin), and its primary mode of action against $E$. coli.

$\dagger$ Present address: Bureau of Sugar Experiment Stations, PO Box 86, Indooroopilly, Queensland, Australia 4068 . 


\section{METHODS}

Chemicals. $\left[{ }^{1+} \mathrm{C}\right]$ Leucine and $\left[{ }^{1+} \mathrm{C}\right]$ uridine were obtained from New England Nuclear. $\left[\right.$ Methyl $\left.-{ }^{3} \mathrm{H}\right]$ thymidine was obtained from International Chemical and Nuclear Corporation, Irvine, Calif., USA. Coumermycin $\mathrm{A}_{1}$, novobiocin, nalidixic acid, and chemicals tested for reversal of inhibition (adenine, cytosine, guanine, thymine, uracil, dATP, dCTP, dGTP, alanine, arginine, aspartic acid, cystine, glutamic acid, glycine, histidine, homoserine, isoleucine, leucine, lysine, methionine, phenylalanine, proline, serine, threonine, tryptophan, tyrosine, valine, $p$-aminobenzoic acid, choline chloride, nicotinic acid, pantothenic acid, riboflavin and thiamine) were purchased from Sigma.

Bacterial strains. Xanthomonas albilineans strain LS2 was isolated from diseased sugarcane from Hawaii. Strain LS20, which produced fourfold higher antibiotic yield in liquid culture, was selected as a colony producing a larger zone of inhibition in the $E$. coli plate bioassay after nitrosoguanidine mutagenesis of strain LS2. E. coli UHPI and Bacillus subtilis UHP101 are prototrophic, wild-type strains and were obtained from the Department of Microbiology, University of Hawaii. E. coli UHP1 was used in assays throughout the study in preference to a K12 strain because $X$. albilineans produces valine in culture, which also inhibits $\mathrm{K} 12$ strains on minimal media. E. coli W3110 and its Pol ${ }_{1}{ }^{-}$derivative (p3478) were obtained from M. Mandel, Department of Biochemistry and Biophysics, University of Hawaii.

Antibiotic production. In preliminary experiments to determine optimum growth conditions for antibiotic production, $X$. albilineans LS2 was grown under a range of culture conditions, and aliquots of culture medium were periodically removed, centrifuged at $20000 \mathrm{~g}$ for $5 \mathrm{~min}$ to remove cells, and assayed for antibiotic activity as described below. Samples were not filter-sterilized before quantitative assay because activity was reduced by adsorption to cellulose ester, polycarbonate and nylon- 66 membrane filters. Maximum activity was obtained in early stationary phase from shaken cultures grown at $28{ }^{\circ} \mathrm{C}$ to $30^{\circ} \mathrm{C}$. Activity was higher in sucrose/peptone medium (SP medium containing $20 \mathrm{~g}$ sucrose, $5 \mathrm{~g}$ peptone, $0.5 \mathrm{~g} \mathrm{~K}_{2} \mathrm{HPO}_{4}, 0.25 \mathrm{~g} \mathrm{MgSO}_{4} .7 \mathrm{H}_{2} \mathrm{O}$ per litre, $\mathrm{pH} 7.0$ ) than in minimal medium ( 5 to $20 \mathrm{~g}$ sucrose, $0.1 \mathrm{~g} \mathrm{~L}$-methionine, $3 \mathrm{~g} \mathrm{~K}_{2} \mathrm{HPO}_{4}, 1 \mathrm{~g} \mathrm{NaH}_{2} \mathrm{PO}_{4}, 1 \mathrm{~g} \mathrm{NH}_{4} \mathrm{Cl}, 0.3 \mathrm{~g}$ $\mathrm{MgSO}_{4} .7 \mathrm{H}_{2} \mathrm{O}$ per litre, $\mathrm{pH} 7 \cdot 0$ ), and addition of sugarcane leaf extract did not increase antibiotic yield. No detectable antibiotic activity was recovered from the washed cell pellet after sonication to disrupt cells.

Thereafter, the antibiotic was prepared from cultures of $X$. albilineans LS20 grown to stationary phase $(96 \mathrm{~h})$ in 2.8 litre Fernbach flasks containing 1.5 litre SP medium, shaken at 200 r.p.m. at $28{ }^{\circ} \mathrm{C}$. Cells were removed by centrifugation and the antibiotic was recovered from the supernate by adsorption to Amberlite XAD-7 resin (Sigma). After elution from XAD-7 resin with methanol, the solvent was evaporated under vacuum, and then the concentrated aqueous residue was adjusted to $95 \%(\mathrm{v} / \mathrm{v})$ acetone and stored for $12 \mathrm{~h}$ at $5{ }^{\circ} \mathrm{C}$ to precipitate inactive high molecular weight material. Further purification involved gel filtration in methanol on a Sephadex LH-20 column (Pharmacia; $120 \times 2.5 \mathrm{~cm}$ ) at a flow rate of $1 \mathrm{ml} \mathrm{min}^{-1}$, followed by reverse phase HPLC on a Hamilton PRP-1 column (Hamilton Co., Reno, Nev., USA; 30.5 $\times 0.7 \mathrm{~cm}$ ) and then a Beckman ODS column (Beckman Instruments; $25 \times 1 \mathrm{~cm})$ using isocratic elution with $44 \%(\mathrm{v} / \mathrm{v})$ tetrahydrofuran in water containing $1 \%(\mathrm{v} / \mathrm{v})$ acetic acid, at a flow rate of $2 \mathrm{ml} \mathrm{min} \mathrm{m}^{-1}$. Antibacterial activity was recovered in a single peak from LH-20 chromatography at $V_{\mathrm{e}}=1$ litre $\left(V_{\mathrm{e}} / V_{0}=5 \cdot 0\right)$, and this material, with a specific activity of $3.5 \times 10^{5} \mathrm{units}^{\mathrm{mg}} \mathrm{m}^{-1}$, was used in mode of action studies unless otherwise indicated. Reverse phase HPLC resolved several antibacterial components. The major component comprising $80 \%$ of the total activity eluted last, at $V_{\mathrm{e}}=78$ to $80 \mathrm{ml}$ on the ODS column. This material was recovered by allowing tetrahydrofuran to slowly evaporate from the pooled fractions from the active peak, and collecting the resulting white crystals by filtration. The product appeared chromatographically pure on analytical octadecylsilane and cyano- and phenyl-bonded phase HPLC columns. The compound (albicidin), with a specific activity of $10^{6}$ units $\mathrm{mg}^{-1}$, was used to confirm and extend results obtained with the mixed components obtained after LH-20 chromatography. An antibiotic stock of $5 \times 10^{4}$ units $\mathrm{ml}^{-1}$ in methanol, stored at $-20^{\circ} \mathrm{C}$, was added directly to liquid cultures, or diluted with sterile water for plate assays.

Antibiotic assay. For quantitative assays of inhibitory activity, $10 \mathrm{ml}$ glucose minimal A agar (Miller, 1972) was poured into $9 \mathrm{~cm}$ Petri dishes and allowed to dry for $48 \mathrm{~h}$ at $25^{\circ} \mathrm{C}$. Plates were then overlaid with a mixture of exponential phase $E$. coli UHPl $\left(2 \mathrm{ml}, 2 \times 10^{7}\right.$ cells ml $\left.^{-1}\right)$ in glucose minimal A medium, plus $2 \mathrm{ml} \mathrm{molten} 2 \%$ $(w / v)$ Noble agar (Difco) at $65^{\circ} \mathrm{C}$. Serial twofold dilutions of test preparations were assayed by adding $20 \mu 1$ volumes to $5 \mathrm{~mm}$ diameter wells cut in the overlaid plates. The width of the zone of growth inhibition surrounding each well was recorded after $12 \mathrm{~h}$ incubation at $37^{\circ} \mathrm{C}$. The quantity of antibiotic causing an inhibition zone $3 \mathrm{~mm}$ wide was arbitrarily designated as one unit of activity. The minimum inhibitory concentration (MIC) in liquid culture corresponds approximately to 50 units $\mathrm{ml}^{-1}$, or 1 unit per $20 \mu \mathrm{l}$ sample added to a $5 \mathrm{~mm}$ well in the plate assay described. The antibiotic activities of individual samples were determined by comparison with a reference standard included on each assay plate, to a void possible errors due to changes in the slope of the dose-response line with slight changes in assay conditions on successive occasions (Hewitt, 1977).

Mode of action of antibiotic. The nucleic acid bases, nucleotides, amino acids and vitamins listed above were tested for their ability to reverse the inhibitory effects of the antibiotic by mixing them individually with the 
antibiotic in wells in overlaid plates. Each compound was tested at $10 \mu \mathrm{g} \mathrm{ml}^{-1}$ applied with 10 units of antibiotic in $20 \mu \mathrm{l}$ to $5 \mathrm{~mm}$ wells in plates overlaid with $E$. coli UHP1, as described above. Compounds were similarly tested as combined metabolic pools (Gerhardt, 1981), including one pool containing all of the listed chemicals.

To determine the effects of the antibiotic on cell viability and morphology, E. coli UHP1 was grown at $37^{\circ} \mathrm{C}$ in glucose minimal A medium. Flasks were inoculated with $1 \%(\mathrm{v} / \mathrm{v})$ of an overnight culture and incubated with shaking in a waterbath to an optical density at $520 \mathrm{~nm}$ of 0.13 as measured in a Bauch \& Lomb Spectronic 20 colorimeter. Cultures were then divided; one part was treated with antibiotic at 50 units $\mathrm{ml}^{-1}(1 \times \mathrm{MIC})$ or 250 units $\mathrm{ml}^{-1}(5 \times \mathrm{MIC})$, and the other was treated with an equal volume of methanol as control. Growth of cultures in side-arm flasks was determined by periodic measurement of the $\mathrm{OD}_{520}$. Samples were removed at intervals, immediately diluted in sterile water, and plated on Difco nutrient agar to determine viable counts. Cells taken directly from liquid cultures $12 \mathrm{~h}$ after addition of antibiotic were negatively stained with $1 \%(\mathrm{w} / \mathrm{v})$ aqueous potassium phosphotungstate and examined by electron microscopy.

To study macromolecule synthesis, $E$. coli UHP1 was grown as described above to an $\mathrm{OD}_{520}$ of 0.08 , then either $\left[{ }^{14} \mathrm{C}\right]$ leucine $\left(5 \mu \mathrm{g} \mathrm{ml}^{-1}, 0.04 \mu \mathrm{Ci} \mathrm{ml}^{-1}\right)$, or $\left[{ }^{14} \mathrm{C}\right]$ uridine $\left(20 \mu \mathrm{g} \mathrm{ml}^{-1}, 0.01 \mu \mathrm{Ci} \mathrm{ml}^{-1}\right)$, or [methyl- ${ }^{-3} \mathrm{H}$ thymidine $\left(1 \mu \mathrm{g} \mathrm{ml}^{-1}, 1.0 \mu \mathrm{Ci} \mathrm{ml}^{-1}\right.$, plus $250 \mu \mathrm{g}$ uridine $\left.\mathrm{ml}^{-1}\right)$ was added to assess synthesis of protein, RNA or DNA respectively $(1 \mu \mathrm{Ci}=37 \mathrm{kBq})$. After $9 \mathrm{~min}$, cultures were divided and either antibiotic or methanol was added as described above. At intervals after the addition of radioactive precursors, $0 \cdot 2 \mathrm{ml}$ samples were removed and treated immediately with $5 \mathrm{ml} 5 \%(\mathrm{v} / \mathrm{v})$ trichloroacetic acid (TCA) at $0{ }^{\circ} \mathrm{C}$. Samples used to assess protein synthesis were heated at $90{ }^{\circ} \mathrm{C}$ for $20 \mathrm{~min}$ and then cooled. After $30 \mathrm{~min}$ on ice, the TCA-insoluble precipitates were collected on Whatman GF/C glass fibre filters and washed four times with $5 \mathrm{ml}$ ice-cold $5 \% \mathrm{TCA}$. The filters were dried at $90^{\circ} \mathrm{C}$ for $1 \mathrm{~h}$, and then radioactivity was measured by liquid scintillation spectrometry.

Antibiotic cross-resistance. Spontaneous mutants of $E$. coli UHP1, resistant to albicidin $\left(0.6 \mu \mathrm{g} \mathrm{ml}^{-1}\right)$, coumermycin $A_{1}\left(50 \mu \mathrm{g} \mathrm{ml}^{-1}\right)$, novobiocin $\left(1000 \mu \mathrm{g} \mathrm{ml}^{-1}\right)$ or nalidixic acid $\left(50 \mu \mathrm{g} \mathrm{ml}^{-1}\right)$, were selected using a gradient plate technique (Gerhardt, 1981). The concentrations of antibiotics used for selecting mutants of $E$. coli were greater than $10 \times \mathrm{MIC}$, which excluded the possibility of selecting mutants with a low level of resistance to antibiotics resulting from changes in permeability. Cross-resistance between antibiotics was then assessed by streaking mutants resistant to albicidin along gradients of the known antibiotics and mutants resistant to each of the known antibiotics along gradients of albicidin. The parent strain and a mutant resistant to the antibiotic under test were also streaked as controls on each gradient plate.

Interaction with DNA in vitro. DNA was isolated from E. coli UHP1 by the method of Marmur (1961). Thermal denaturation behaviour in dilute saline-citrate (Marmur, 1961) was determined for $25 \mu \mathrm{g} \mathrm{DNA} \mathrm{ml}^{-1}$ plus 0,1 and $5 \mu \mathrm{g}$ albicidin $\mathrm{ml}^{-1}$ (antibiotic/DNA nucleotide molar ratios of $0,0.025$ and $0 \cdot 125$, assuming a molecular weight of 600 for albicidin). The effects of DNA on the absorption spectrum of albicidin were recorded in $0 \cdot 01 \mathrm{M}-\mathrm{Tris} / \mathrm{HCl}$ buffer, $\mathrm{pH} 7 \cdot 0$, in the presence and absence of $30 \mu \mathrm{M}-\mathrm{Mg}^{2+}$ which may act as an inhibitor or a cofactor in the binding of antibiotics to DNA (Edwards, 1980).

Interaction with DNA in vivo. The DNA-modifying activity of albicidin in vivo was tested using the standard PolA plate assay described by Rosenkranz \& Leifer (1980).

\section{RESULTS}

\section{Chemical characteristics of albicidin}

The yield of purified albicidin was approximately $0.2 \mathrm{mg}$ per litre of culture. The compound was soluble in methanol, tetrahydrofuran, DMSO and $95 \%$ acetone, sparingly soluble in water and acetonitrile, and essentially insoluble in less polar solvents. Albicidin was irreversibly adsorbed from aqueous solutions onto activated charcoal. Spot tests with common spray reagents (Stahl, 1969) gave reactions typical of acid and phenol groups. Inhibitory activity was undiminished after $30 \mathrm{~min}$ at $100^{\circ} \mathrm{C}, 3 \mathrm{~h}$ at $37^{\circ} \mathrm{C}$ with $50 \mu \mathrm{g}$ pronase $\mathrm{ml}^{-1}$, or $3 \mathrm{~h}$ at $25^{\circ} \mathrm{C}$ at $\mathrm{pH} 1.0$, but was eliminated within $3 \mathrm{~h}$ at $25^{\circ} \mathrm{C}$ at $\mathrm{pH} 10.0$. The $\mathrm{UV}$ absorption spectrum in methanol showed peaks at $213 \mathrm{~nm}$ and $308 \mathrm{~nm}\left(A_{1 \%}^{1 \%} 8 \times 10^{2}\right)$. Addition of KOH to $0.06 \mathrm{M}$ shifted the $308 \mathrm{~nm}$ absorption peak to $320 \mathrm{~nm}$ with a shoulder near $350 \mathrm{~nm}$. In aqueous solution at pH 7 the peak was at $308 \mathrm{~nm}$ with a shoulder at $275 \mathrm{~nm}$ (Fig. 1). Partial characterization of albicidin by proton and ${ }^{13} \mathrm{C}$ NMR spectroscopy suggests that the compound has several aromatic rings and approximately 38 carbon atoms ( $\mathrm{R}$. E. Moore, personal communication). Albicidin stocks were stored in methanol at $-20^{\circ} \mathrm{C}$ for up to 6 months without a decline in activity. However, in solutions kept at room temperature albicidin was gradually converted to a compound which eluted $8 \mathrm{ml}$ before albicidin during HPLC on the ODS column described above, with the $308 \mathrm{~nm}$ absorption peak shifted to $288 \mathrm{~nm}$, and with concomitant loss of antimicrobial activity. 


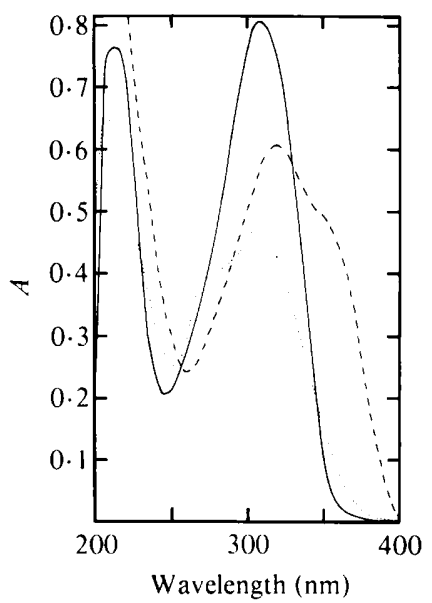

Fig. 1

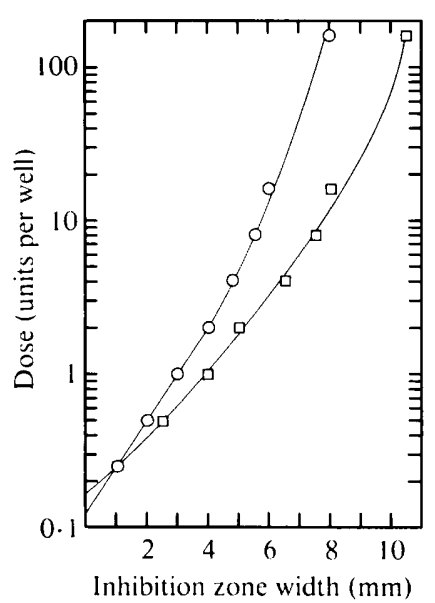

Fig. 2

Fig. I Absorption spectra of albicidin $\left(10 \mu \mathrm{g} \mathrm{ml}^{-1}\right)$ in: - , methanol; ---, $0.06 \mathrm{M}$-methanolic $\mathrm{KOH}$; $\cdots, 0 \cdot 01 \mathrm{M}$-Tris/HCl buffer, $\mathrm{pH} 7 \cdot 0$.

Fig. 2. Dose-response relationships for inhibition of growth of E. coli UHPI (O) and B. subtilis UHPI01 ( $\square$ ) by albicidin. Plate assay conditions are described in Methods. The results shown are from a typical experiment.
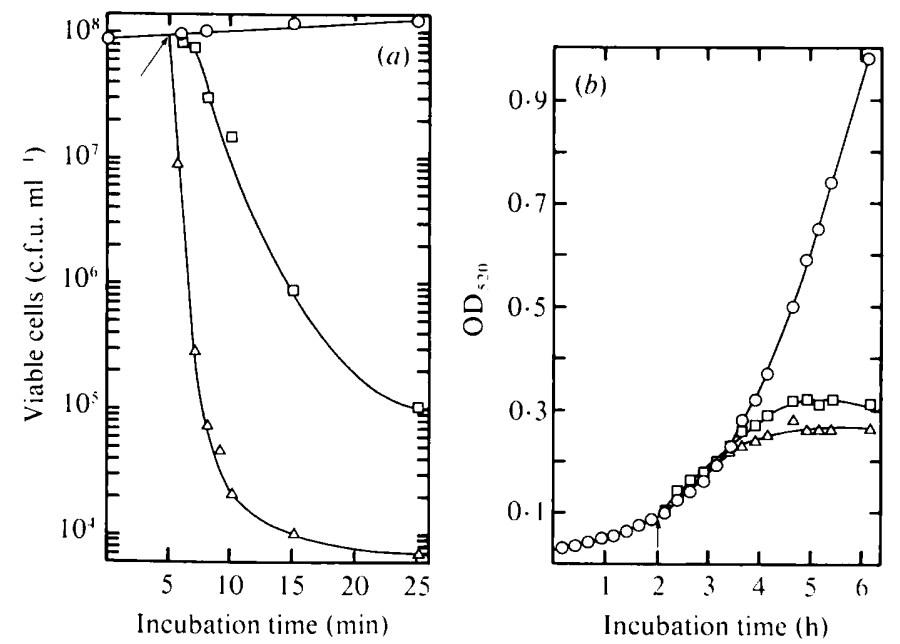

Fig. 3. Effect of the antibiotic mixture from $X$. albilineans on growth and viability of $E$. coli UHP1. Arrows indicate time of addition of the antibiotic to exponentially growing cultures. Viable cell counts $(a)$ and culture optical density $(b)$ were determined at intervals as described in Methods. $\bigcirc$, Control; $\square$, albicidin ( 1 unit per $20 \mu \mathrm{l}) ; \triangle$, albicidin $(5$ units per $20 \mu \mathrm{l}) ; 1$ unit per $20 \mu \mathrm{l}$ is approximately the MIC. The results shown are from a typical experiment.

\section{Mode of action of albicidin}

Dose-response relationships for inhibition of $E$. coli UHP1 and B. subtilis UHP101 by albicidin are shown in Fig. 2. Inhibition of $E$. coli UHP1 was not reversed by any tested combination of amino acids, nucleotides and vitamins, or by $1 \%(\mathrm{w} / \mathrm{v})$ yeast extract mixed in the overlayer, or added to wells with the antibiotic. At 1 to $5 \times$ MIC in liquid culture, albicidin was rapidly bactericidal to $E$. coli UHPl (Fig. $3 a$ ), although growth as measured by the increase in optical density continued for $1 \mathrm{~h}$ after addition of the antibiotic (Fig. $3 b$ ). Many E. coli cells from albicidin-treated cultures contained large inclusions resembling polyphosphate granules, but there was no evidence of cell lysis. 


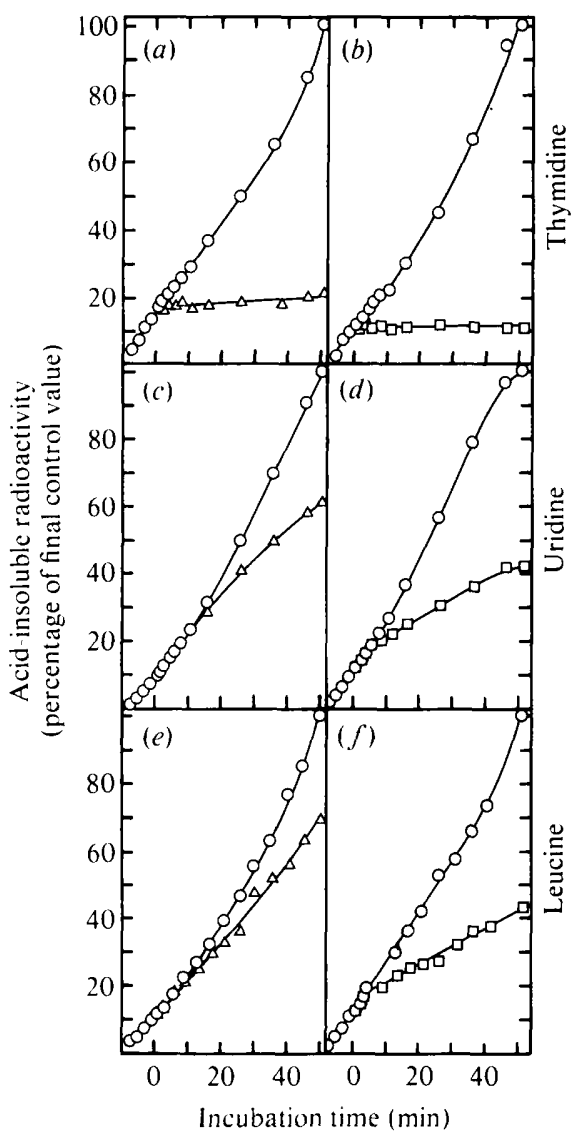

Fig. 4. Effect of albicidin on synthesis of DNA $(a, b)$, RNA $(c, d)$, and protein $(e, f)$ in $E$. coli UHPl. Labelled precursors (thymidine, uridine and leucine) were added to exponentially growing cultures 9 min before addition of albicidin at time zero, to $50 \mathrm{ng} \mathrm{ml}^{-1}(a, c, e)$ or $150 \mathrm{ng} \mathrm{ml}^{-1}(b, d, f)$. $\bigcirc$, Control, $\triangle$, albicidin $\left(50 \mathrm{ng} \mathrm{ml}^{-1}\right): \square$, albicidin $\left(150 \mathrm{ng} \mathrm{m}^{-1}\right) ; 50 \mathrm{ng} \mathrm{m}^{-1}$ is approximately the MIC. Radioactivity incorporated into the acid-insoluble fraction was determined at intervals, as described in Methods. Final c.p.m. $\mathrm{ml}^{-1}$ for control samples, plotted as 100 radioactivity units, were $(a) 13.3 \times 10^{3}$; (b) $19.6 \times 10^{3} ;(c) 21.7 \times 10^{4} ;(d) 95.7 \times 10^{3} ;(e) 49 \cdot 1 \times 10^{3} ;(f) 31.3 \times 10^{3}$. The results shown are from a typical experiment.

At the MIC in liquid culture, DNA synthesis was inhibited nearly completely within 2 to 3 min of addition of albicidin. Synthesis of RNA and protein were partially inhibited 8 to $10 \mathrm{~min}$ after addition of antibiotic. A threefold higher dose $(3 \times$ MIC) resulted in immediate and complete inhibition of DNA synthesis and partial inhibition of RNA and protein synthesis after 6 to $8 \mathrm{~min}$ (Fig. 4). Based on the incorporation of radioactive precursors in the first $50 \mathrm{~min}$ after addition of the higher antibiotic dose $(3 \times \mathrm{MIC})$, the degree of inhibition was $100 \%$ for DNA synthesis, $65 \%$ for RNA synthesis and $64 \%$ for protein synthesis. With the mixed components for LH-20 chromatography at an equivalent dose, the kinetics of inhibition of macromolecule synthesis were essentially identical to those shown in Fig. 4.

Because inhibitors of DNA gyrase and antibiotics binding to DNA can yield similar patterns of inhibition of macromolecule synthesis (Smith \& Davies, 1967; White \& White, 1967; Wolfe, 1975), we attempted to distinguish between these possible modes of action of albicidin. A total of 24 spontaneous mutants of $E$. coli UHP1 resistant to albicidin, coumermycin $\mathrm{A}_{1}$, novobiocin, or nalidixic acid showed no cross-resistance between albicidin and inhibitors of DNA gyrase. Albicidin at 1 or $5 \mu \mathrm{g} \mathrm{ml}^{-1}$ did not alter the thermal denaturation behaviour of isolated $E$. coli DNA $\left(40 \%\right.$ total hyperchromicity and $T_{\mathrm{m}}=75.5^{\circ} \mathrm{C}$ in $0.18 \mathrm{M}$-sodium citrate). The absorption 
spectrum of $5 \mu \mathrm{g}$ albicidin $\mathrm{ml}^{-1}$ in $0.01 \mathrm{M}-\mathrm{Tris} / \mathrm{HCl}, \mathrm{pH} 7$, was unaltered in the presence of $30 \mu \mathrm{M}$ $\mathrm{MgCl}_{2}, 50 \mu \mathrm{g} \mathrm{DNA} \mathrm{ml}{ }^{-1}$, or $\mathrm{MgCl}_{2}$ plus DNA. Serial twofold dilutions of albicidin caused equal zones of growth inhibition against E. coli $\mathrm{W} 3110$ and its PolA ${ }^{-}$derivative in replicated standard PolA plate assays.

\section{DISCUSSION}

The results support the conclusion that inhibition of DNA synthesis is a primary mode of action of albicidin against $E$. coli. Incorporation of labelled thymidine into DNA was rapidly and completely inhibited by albicidin prior to loss of viability. Incorporation of precursors into RNA and protein was only partially inhibited, and slightly delayed. Although the bactericidal action of albicidin was rapid and irreversible, cell growth was blocked only after one generation time. Moreover, affected cells were not lysed but many accumulated large polyphosphate granules, which is a characteristic response to impaired nucleic acid synthesis (Stanier et al., 1976).

The blockage of DNA synthesis by albicidin during the exponential phase of growth could be due to an action on precursor uptake, changes in precursor pool sizes or competition with precursor nucleosides or nucleotides. However, the speed with which DNA synthesis was blocked on addition of albicidin to cells indicated rapid penetration and direct inhibition of the polymerizing system. The irreversibility of the bactericidal effect on cells briefly treated with albicidin above the MIC suggested efficient binding of the antibiotic to its target. Because total inhibition of DNA synthesis and partial inhibition of RNA synthesis resulted, either the DNA template itself, or a protein such as DNA gyrase with functions in both DNA replication and transcription are potential targets (Smith \& Davies, 1967; White \& White, 1967; Wolfe, 1975). It seems possible that albicidin specifically blocks an essential replication protein, and that the apparent partial inhibition of RNA synthesis simply reflected the increasing DNA available for transcription in rapidly growing, untreated control cultures. Continuing incorporation of labelled uridine mainly measures stable rRNA synthesis, while protein synthesis rapidly reflects availability of short-lived mRNA in prokaryotes (Oostra et al., 1981). Thus the nearly identical decrease in uridine and leucine incorporation after albicidin treatment indicated no differential effect on rRNA versus mRNA synthesis.

Gyrase inhibitors fall into two groups typified by nalidixic acid, which interacts with gyrase subunit $A$, and coumermycin $A_{1}$, which acts on subunit $B$. Cross-resistance is usually observed among inhibitors in each group (Yamagishi et al., 1981). Thus albicidin seems unlikely to act as a DNA gyrase inhibitor, since mutants of $E$. coli showed no cross-resistance between albicidin and inhibitors of either gyrase subunit. Moreover, gyrase inhibitors, in contrast to albicidin, cause preferential inhibition of rRNA synthesis (Oostra et al., 1981).

Binding of intercalating drugs characteristically increases the temperature of thermal denaturation of DNA. Intercalators and other antibiotics which bind to DNA commonly show changes in their absorption spectra on binding (Edwards, 1980). Neither of these effects was observed on mixing pure albicidin and E. coli DNA in vitro. E. coli $\mathrm{PolA}^{-}$is more sensitive than its $\mathrm{PolA}^{+}$parent strain to chemicals which alter DNA, including compounds such as the mitomycins which must first be activated in vivo (Rosenkranz \& Leifer, 1980). Equal inhibition of PolA ${ }^{-}$and PolA ${ }^{+}$strains by albicidin indicated that this compound did not bind to or modify DNA. Selective inhibition of DNA synthesis without evidence of DNA binding suggested a specific interaction with DNA polymerases or other proteins essential for DNA, replication (Kornberg, 1980). Further studies are required to establish which interaction occurs with albicidin. Elucidation of the structure of albicidin may simplify the choice of experimental approaches to determining the action of this compound at the molecular level.

Antimicrobial agents have not previously been reported from the genus Xanthomonas, and the combined biological and chemical properties of albicidin do not appear to resemble closely those of any known antibiotic. The similar chromatographic behaviour of all components of the antibiotic mixture produced in culture by $X$. albilineans suggested that these components, including albicidin, comprised a family of structurally related compounds, as is commonly 
observed for secondary metabolites. Insufficient quantities of the minor components were available to allow confirmation of this hypothesis by chemical characterization.

Since chloroplasts appear to use prokaryote mechanisms of DNA replication, transcription and translation, it is possible that albicidin, or a structural analogue produced in diseased plants, may be involved in the blocked chloroplast differentiation which characterizes sugarcane leaf scald chlorosis (Birch \& Patil, 1983). The antibiotic mixture obtained after LH-20 chromatography does not cause chlorosis when injected into sugarcane at concentrations up to $10^{4}$ units $\mathrm{ml}^{-1}$. However, preliminary results with mutants and revertants in antibiotic production show a strong correlation between the ability to produce albicidin and the ability to cause chlorosis in invaded plants. We have now extended those mutant studies and examined the effects of albicidin on macromolecule synthesis in isolated chloroplasts; the results will be reported in a subsequent paper.

We thank W. Ego for the strains of E. coli and B. subtilis; M. Mandel and T. Grover for assistance with thermal denaturation studies; and R. E. Moore for unpublished NMR spectra and advice on chemical characterization. We also thank M. Mandel for a critical review of the manuscript.

This paper is no. 2894 in the Journal Series of the College of Tropical Agriculture and Human Resources, University of Hawaii, Honolulu, Hawaii 96822, USA.

\section{REFERENCES}

BiRCH, R. G. \& PATIL, S. S. (1983). Blocked chloroplast differentiation in sugarcane leaf scald disease. Phytopathology 73, 1368-1374.

EDWards, D. J. (1980). Antimicrobial Drug Action, pp. 158-185. Baltimore: University Park Press.

Gasson, M. J. (1980). Indicator technique for antimetabolic toxin production by phytopathogenic species of Pseudomonas. Applied and Environmental Microbiology 39, 25-29.

GERHARDT, P. (editor) (1981). Manual of Methods for General Bacteriology, p. 234. Washington, DC: American Society for Microbiology.

HewITT, W. (1977). Microbiological Assay. New York: Academic Press.

Kornberg, A. (1980). DNA Replication, pp. 434-440. San Francisco: W. H. Freeman \& Co.

MARMUR, J. (1961). A procedure for the isolation of deoxyribonucleic acid from micro-organisms. Journal of Molecular Biology 3, 208-218.

Miller, J. H. (1972). Experiments in Molecular Genetics, pp. 431-432. Cold Spring Harbor: Cold Spring Harbor Laboratory.

Oostra, B.A., Van Vliet, A. J., Ab, G. \& Gruber, M. (1981). Enhancement of ribosomal ribonucleic acid synthesis by deoxyribonucleic acid gyrase activity in Escherichia coli Journal of Bacteriology 148, 782-787.

Rosenkranz, H. S. \& LeIFER, Z. (1980). Determining the DNA modifying activity of chemicals using DNA-polymerase-deficient Escherichia coli. In Chemical Mutagens, vol. 6, pp. 108-147. Edited by A.
Hollander \& F. J. de Serres. New York: Plenum Press.

SMITH, D. J. \& DAviEs, B. I. (1967). Mode of action of novobiocin in Escherichia coli. Journal of Bacteriology 93, 71-79.

STAHL, E. (editor) (1969). Thin-layer Chromatography, 2nd edn, pp. 855-909. New York: Springer-Verlag.

Stanier, R. Y., AdelberG, E. A. \& Ingraham, J. (1976). The Microbial World, 4th edn, p. 356. Englewood Cliffs, New Jersey: Prentice Hall.

Staskawicz, B. J. \& Panopoulos, N. J. (1979). A rapid and sensitive microbiological assay for phaseolotoxin. Phytopathology 69, 663-666.

White, H. L. \& WhITE, J. R. (1967). Binding of rubiflavin to deoxyribonucleic acid in relation to antibacterial action. In Proceedings of the Sixth Interscience Conference on Antimicrobial Agents and Chemotherapy, Philadelphia, USA, 1966, pp. 227-234. Edited by G. L. Hobby. Washington, DC: American Society for Microbiology.

WOLFE, A. D. (1975). Quinacrine and other acridines. In Antibiotics III, pp. 203-233. Edited by J. W. Corcoran \& F. E. Hahn. New York: SpringerVerlag.

Yamagishi, J., Furutani, Y., Inoue, S., Okue, J., Nakamura, S. \& ShimizU, M. (1981). New nalidixic acid resistance mutations related to deoxyribonucleic acid gyrase activity. Journal of Bacteriology 148, 450-458. 